\title{
ANALYSIS OF ISLAMIC LAW AND LAW NO. 56 PRP 1960 ON THE PRACTICE OF PAWNING PADDY FIELDS IN THE VILLAGE OF MALANG
}

\author{
Hanik Musyarofah \\ MA Al Ittihad Malang \\ nuhaq237@gmail.com
}

\begin{abstract}
This is field research entitled "Review of Islamic Law and Law Number 56 Prp of 1960 Against Pawn Pawn Practices in Jambesari Village, Poncokusumo District, Malang Regency". This study has two objectives, namely: how the practice of pawning rice fields in Jambesari Village, Poncokusumo District, Malang Regency and how to analyze Islamic law and Law no. 56 Prp Th. 1960 on the practice of pawning rice fields in Jambesari Village, Poncokusumo District, Malang Regency. The results of this study are that: first, the practice of pawning rice fields by the people of Jambesari Village, Poncokusumo District, Malang Regency is carried out by making an oral pawn agreement from both parties for a certain period; and second, the practice of pawning rice fields in Jambesari Village, Poncokusumo District, Malang Regency is in accordance with the opinion of the Hanafiyah scholars. However, contrary to the number of Maliki, Shafi'i and Hanbali scholars, it is mainly related to the use of pawned land which tends to have an element of coercion.
\end{abstract}

Keywords: Pawn fields, land area, Islamic law

\begin{abstract}
Abstrak: Ini adalah penelitian lapangan yang berjudul "Tinjauan Hukum Islam dan Undang-Undang Nomor 56 Prp tahun 1960 Terhadap Praktik Gadai Sawah di Desa Jambesari Kecamatan Poncokusumo Kabupaten Malang". Dalam penelitian ini ada dua rumusan masalah yang akan dibahas, yaitu: bagaimana praktik gadai sawah di Desa Jambesari Kecamatan Poncokusumo Kabupaten Malang dan bagaimana analisis hukum Islam dan UU No. 56 Prp Th. 1960 terhadap praktik gadai Sawah di Desa Jambesari Kecamatan Poncokusumo Kabupaten Malang. Hasil penelitian ini adalah bahwa: pertama, Praktik gadai sawah oleh masyarakat Desa Jambesari Kecamatan Poncokusumo Kabupaten Malang dilakukan dengan cara membuat perjanjian gadai sawah secara lisan dari kedua belah pihak selama kurun waktu tertentu; dan kedua, praktik gadai sawah di Desa Jambesari Kecamatan Poncokusumo Kabupaten Malang sesuai dengan pendapat ulama Hanafiyah. Akan tetapi bertentangan dengan jumhur ulama Maliki, Syafi'i dan Hanbali terutama terkait dengan pemanfaatan tanah gadai yang cenderung ada unsur paksaan.
\end{abstract}

Kata Kunci: Gadai sawah, luas lahan, hukum Islam

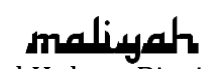

Jurnal Hukum Bisnis Islam

Volume 11, Nomor 02, Desember 2021

p-ISSN: 2088-4869/ e-ISSN: 2597-4351 


\section{Introduction}

Islam is the religion of rahmah li al-alamin. because all aspects of life are regulated in it, religion regulates relations, both with the creator who we know as "habl min Allah" and with his creatures "habl min al-nas". In relation to humans, one of them we call the relationship muamalah. In a simple sense, mumalah means "relationship between people and people". This describes an activity carried out between one person and another in order to meet their needs ${ }^{1}$

This shows that humans always need each other to meet their needs, so humans are called social creatures, namely creatures who are always in touch with each other. Humans will not be able to achieve what they want without the help of others. Islam is here to bring various solutions to problems, both worship (ritual) and social (muamalah). Explaining the meaning that is still general, thus will be able to explore various solutions to problems that arise in human life.

The obligation for every believer to help each other in doing good / can be realized through the practice of pawning. This practice is intended as a form of tabarru' contract, namely as an application of Allah's commands. in terms of helping. So pawning the fields is one of the muamalah activities that are usually carried out by rural communities in realizing the tabarru' contract.

Pawn fields can be in the form of paddy fields, fields and essays. When someone needs money to meet their needs and needs a fast, uncomplicated way to get money, it is the fields that are used as collateral objects as evidence of a debt commitment to be repaid. The rice fields that are used as objects of debt guarantee are handed over to the murtahin to be used as long as the rahin has not been able to pay off the

\footnotetext{
${ }^{1}$ Abd. Rahman Ghazaly, Fiqh Muamalat (Surabaya: Prenada Media, 2018), 3.
} 
debt. The murtahin takes advantage of the rice field, in this case it is as if the rice field belongs to the murtahin

The purpose of the pawn is to ask for trust and guarantee the debt, not to seek profit from the pawn. ${ }^{2}$ If a murtahin uses marhun even if he gets permission from Rahin, then it encourages the practice of usury which is forbidden, because it is the same with debt that makes benefits and the form of debt that flows benefits is usury. This is in accordance with the hadith:

"Every debt that attracts benefits is usury" (HR. alBaihaqi) ${ }^{3}$

Meanwhile, in Article 7 paragraph (1) of Law Number 56 Prp of 1960 concerning Determination of Agricultural Land Areas (hereinafter known as Law No. 56 Prp of 1960) which reads "Whoever controls agricultural land with a lien right When this regulation comes into force 7 years or more, it is obligatory to return the land to its owner within a month after the existing crops have been harvested, with no right to demand a ransom payment."

From the article, it has been explained that in terms of ownership of agricultural land it is valid for 7 years, when it has reached 7 years or more, the pawnbroker is required to return the land to the owner within a month after the existing crops are harvested without any ransom. The use of rice fields does not stop at pure use by the murtahin, but there are also murtahin parties who cooperate in fields that are not actually the property of the murtahin, they use it for cooperation in the fields without the knowledge of Rahin. And the results are purely enjoyed by the murtahin and the people who work with the murtahin. The application of such pawns occurred in Jambesari Village, Poncokusumo District, Malang Regency.

2 Sayyid Sabiq, Fikih Sunnah, terj. Kamaluddin A. Marzuki (Bandung: AlMa'rif, 1997), 141.

3 Abdullah bin Abdurrahman, Taudih al-Ahkam Bulugh al-Maram, juz 4 (Makkatul Mukarromah: Maktabah Adh-Dhikri), 472. 
Apart from the full utilization controlled by the murtahin and the use without their knowledge, regarding the time period when the rahin is due, the rahin still cannot pay off the forest, the full utilization of the rice fields by the murtahin then the rice fields remain in the hands of the murtahin until they can pay off their debts.

\section{The Concept of Rahn in Islamic Law}

Rahn etymologically, means al-thubut "permanent" and al-dawam "eternal, permanent, continuous". Some say rahn means "permanent and sustainable" can also be called al-habsu and al-luzum means "detention". Allah says in the Qur'an Surah al-Mudatsir verse 38;

"each person is responsible for what he does." (Q.S. alMudaththir: 38) ${ }^{4}$

According to Islamic legal terms, fiqh scholars define rahn as withholding something because of a right that allows that right to be fulfilled from that thing. ${ }^{5}$ It means making goods that have value according to Islamic law as collateral for debts, so that the person is allowed to take debts or take some of the benefits of the goods ${ }^{6}$. Making goods as collateral for debt that can be used as debt payers if the debtor cannot repay the debt. In short, that rahn is a debt contract by making goods of value according to debt security until the debtor pays off the debt. As for rahn's Legal Foundation is:

"If you are on a journey (and don't even pay cash) and you do not find a writer, then there should be collateral held (by the debtor). But if some of you believe in others, then let the one who is trusted fulfill his mandate (debt) and let him fear Allah his Lord; And do not (witnesses) hide your

\footnotetext{
${ }^{4}$ Kementrian Agama RI, Al-Qur'an dan Terjemahanya (Surabaya: UD Halim, 2013), 575.

${ }^{5}$ Wahbah Az-zuhaili, Fiqih Islam Wa Adillatuhu (Jakarta: Gema Insani, 2007), 107.

6 Sayyid Sayyid, Fikih Sunnah, terj. Kamaluddin A. Marzuki (Bandung: AlMa'rif, 1997), 187.
} 
testimony. And whoever hides it, then indeed he is a sinner in his heart; And Allah is Knowing of what you do". (Q.S. al-Baqaroh: 283) ${ }^{7}$

Scholars agree that the legal rahn is permissible, both when traveling and in a permanent state. The verse above only shows a valid habit and not a requirement, because in ancient times when traveling it was difficult to find a scribe, in contrast to today's people are already good at writing. Therefore, the verse just wants to show someone an easy form of guarantee for them when they don't find someone who will be their scribe, who will write down debts or other transactions with non-cash payments. Next is the hadith of the Prophet Muhammad SAW:

"Has told us Qutaibah has told us Jarir from al-A'masy from Ibrahim from al-Aswad from 'Aisha radiallahu 'anha said: Rasulullah sallallaahu 'alaihi wasallam once bought food from the Jews by pawning (as collateral) his armor " (HR. Bukhari) ${ }^{8}$

From this hadith, it can be understood that Islam does not discriminate between Muslims and non-Muslims in the field of muamalah, so when a Muslim owes a debt to a non-Muslim, he must continue to pay his debt. ${ }^{9}$

Next is in the form of ijma 'ulama: "Regarding the proposition of ijma', Muslims agree (ijma') that broadly speaking, the rahn (pawning/debt guarantee) contract is permissible." 10 so rahn according to the agreement of legal scholars is allowed. Because in it grows maslahah for both rahin and murtahin, pawning is the confirmation and guarantee

\footnotetext{
${ }^{7}$ Kementrian Agama RI, Al-Qur'an dan Terjemahanya..., 49.

${ }^{8}$ Abdul 'Aziz bin Abdullah bin Abdul Al-Rahman bin Baz, Majmu' Fatawa wa Maqalatun Mutanawwi'atun (Riyadh: Darul Qasim li Al-Nashr, 2001), 254.

9 Hendi Suhendi, Fiqh Muāmalah (Jakarta: PT. Raja Grafindo Persada, 2011), 107.

${ }^{10}$ Abdur Rahman Shobir Husain, Al-Sabil Fi Ushul Al-Fiqh, juz 13 (Libanon: DKi, 1971), 138.
} 
of debt with the goods directly held by the murtahin, so it is easy for him to get debt payments by selling the goods with the permission of the judge or the owner of the goods when rahin is unable to pay his debts. . In addition to the murtahin, rahin also gets something they need in cash and can postpone the payment of their debt in accordance with a predetermined time accompanied by collateral. ${ }^{11}$

\section{The Pillars and Conditions of Rahn}

Pillars according to Hanafi scholars are something that is part of something, whether or not something is there depends on that thing. ${ }^{12}$ Meanwhile, according to the majority of scholars, the pillars are something that determines whether something exists or not and it is impossible for something to exist except with the existence of that thing. Either of that something is part of that thing or not. Aqid (people who have a contract) is one of the pillars of the contract, and a contract is not possible unless there are people who have the contract, namely rahin and murtahin.

Conditions are something that requires before the occurrence of the contract. This means that a contract will not take place unless the conditions specified by the shara' have been fulfilled. Among the pillars and conditions for pawning are: (1) 'aqidain, namely both parties who make the contract, the person who pawns (rahin) and the person who gives the credit (murtahin) must be competent (ahliyah); (2) goods that are pawned (marhun) are assets that are used as collateral to obtain the fulfillment of their rights, namely receivables by the murtahin to rahin.

In this case, Imam Maliki is of the opinion that in pawning there must be a contract, rahin is required to submit collateral to be controlled by the murtahin, in contrast to Imam Shafi'i who does not allow the murtahin to take advantage of

\footnotetext{
${ }^{11}$ Wahbah Az-Zuhaili, Fiqih Islam..., 110.

12 Ibid., 111.
} 
the goods that have been pawned by the rahin. The utilization right is only allowed if it does not harm the womb.

Meanwhile, regarding the conditions for the object being pawned or commonly called marhun according to Hanafi scholars, it is:13 (1) marhun must be able to be sold; (2) marhun must be in the form of property; (3) pawn the benefits; (4) marhun must have value; (5) marhun must be clear and definite; (6) debt (marhun bih). Marhun bih is a right because the mortgage is given. That is the responsibility of the rahin's debt to the murtahin.

\section{Taking Benefits and Risks of Damage to Pawned Goods}

In terms of taking the benefits of the pawned goods, the scholars differed in opinion, including Jumhur ulama and Ahmad. Many scholars are of the opinion that the murtahin should not take a benefit from the pawned goods even if the rahin allows him to use it, because this is part of the debt that attracts benefits, so it is riba if he continues to use it. ${ }^{14}$

According to Imam Ahmad, Ishak, Al-Laits, and AlHasan, if the mortgaged goods are in the form of vehicles that can be used and livestock for which milk can be taken, the recipient of the pledge may benefit from both by adjusting the maintenance costs incurred during the vehicle or livestock. it's on him. In a hadith the Prophet Muhammad explained:

"Has told us Abu Nu'aim has told us Zakariya' from 'Amir from Abu Hurairah radiallahu 'anhu from the Prophet sallallaahu 'alaihi wasallam said: "Anything (animal) that is pawned can be ridden to be used, as well as animal milk can be drunk if pawned". (HR. Bukhari)

Taking advantage of the objects that have been pawned, emphasized on the cost or labor for maintenance. So that the

\footnotetext{
${ }^{13}$ Wahbah Az-Zuhaili, Fiqih Islam..., 133.

${ }^{14}$ Hendi Suhendi, Fiqh..., 107.
} 
holder of the goods that have been pawned, as in the example above, is obliged to carry out maintenance on them. ${ }^{15}$

As for the marhun in the possession of the murtahin, the murtahin is not obliged to replace it, unless it is damaged or the marhun is lost due to the negligence of the murtahin. According to Imam Hanafi, if the murtahin holds the marhun, the murtahin will be the one who will bear the risk of damage or loss of the marhun, whether due to negligence or not. From these two opinions, it can be concluded that there is a difference of opinion. According to Imam Hanafi, the murtahin is obligated to bear the risk of damage or loss of marhun, whether due to negligence or not. Meanwhile, according to Imam Syafi'i, the murtahin bears the risk if the marhun is damaged or lost due to the murtahin. ${ }^{16}$

\section{The end of the Pawn Agreement}

In a pawn agreement, if the debtor dies and the heirs are still children, then the pawned goods will be sold to pay off the debt. If the heirs are adults, then they will replace and are obliged to complete the contract until the debt is paid off. If the person who dies is from the holder of the pawn, it also does not result in the end of the pawn contract but will be continued by the heirs in order to guarantee the rights to the debt. ${ }^{17}$ The person who pledged the pawn may also cancel the pawned item before handing it over. In other words, rahin may cancel the pawn transaction before handing over the goods to be pawned. ${ }^{18}$ Allah SWT says in Surah Al-Baqarah 283.

"... then let there be dependents that are held ..." (Q.S. alBaqarah:283) ${ }^{19}$

\footnotetext{
${ }^{15}$ Hendi Suhendi, Fiqh..., 109.

${ }^{16}$ Hendi Suhendi, Fiqh..., 110.

17 Ahmad Basyir Azhar, Asas-asas Hukum Mu'amalat (Hukum Perdata Islam) (Yogyakarta: UII Press), 132.

${ }^{18}$ Al-Qadhi Abu Syuja, Fiqih Sunnah Imam Syafi'i..., 259

${ }^{19}$ Kementrian Agama RI, Al-Qur'an dan Terjemahanya..., 49.
} 
If the pawned item has been returned to the rahin with a murtahin wish, the contract will be void ${ }^{20}$ To ensure that no party is harmed, conditions are not allowed, for example in a pawn agreement saying "if rahin is unable to pay her debt, then marhun will become the property of the murtahin in exchange for paying off the debt". From these words, it could be that the rahin will benefit if the land is worth less than the debt owed to the murtahin, on the other hand, it may be the murtahin who will benefit if the marhun has a higher value than the debt owed to the rahin. If the person receiving the pledge has received part of the ransom, then the pawned item is not entitled to be returned unless the entire debt has been paid off to the murtahin. ${ }^{21}$ Otherwise the rahin frees him. ${ }^{22}$

If within a predetermined period the rahin has not been able to pay off the debt, the murtahin has the right to sell the marhun at a general price, either bought by the murtahin himself or sold to other parties. And the result is taken by the murtahin for the amount owed to the rahin and the rest is given to the rahin. If the sale of marhun is less than the amount owed to the murtahin, then rahin still has a debt to the murtahin. ${ }^{23}$

Mu'awiyah bin Abdullah bin Ja'far narrated that there was a person who had pawned his house in Medina for a certain period, after it was due the rahin still could not pay off his debt, then the murtahin declared that the house was his. ${ }^{24}$. In a hadith the Prophet Muhammad explained:

"The holder of the pledged property shall not hinder the rights to the pawned property from the rahin who has pawned it. Rahin has the right to get his share and he is obliged to pay the fine"

\footnotetext{
${ }^{20}$ Sayyid Sabiq, Fiqih Sunnah ..., 191.

${ }^{21}$ Sayyid, Fiqih Sunnah 4..., 259.

22 Ibid., 191.

${ }^{23}$ Hendi Suhendi, Fiqh Muamalah..., 110.

${ }^{24}$ Sayyid Sabiq, Fiqih Sunnah..., 191.
} 
From the hadith rahin still has the right to the goods that have been pawned. Provide an opportunity to get time relief to pay off debts or sell goods that have been pawned and then divided according to their respective portions.

\section{The Concept of Pawning in the Law. No. 56 Prp 1960}

In Article 7 paragraph (1) and Article 10 of Law no. 56 Prp Th. 1960 concerning Determination of Agricultural Land Areas, it is regulated about the time limit for controlling agricultural land which is used as collateral for pledges so as not to harm the public interest, then ownership and control of land that exceeds the limit is not allowed. This regulation also regulates the pawning of agricultural land. What is meant by pawn is the relationship between a person and land belonging to another person, who owes money to him. If the debt has not been paid in full, the land remains in the control of the lender or the holder of the pledge. During that time the entire proceeds of the land became the rights of the holder of the lien, which thus constituted the interest on the debt.

Redemption of the land depends on the will and ability of the mortgagee. Many pawns last for years, decades, and some are even continued by the pawnbroker's heirs and pawnbrokers because the pawnbroker is unable to redeem the land. In some areas there is also a pawn where the yield of the land is not only interest, but also installments. Such a pawn is called "selling in installments".

In contrast to ordinary mortgages, in installment sales, after a period the land returns to the pawnbroker without paying a ransom). The amount of the mortgage money depends not only on the fertility of the land but especially on the need for credit. Therefore, it is not uncommon for fertile land to be mortgaged with low mortgages. Usually, people pawn their land only when he is in a very urgent situation. If their needs are not urgent, people usually prefer to rent out their land. In connection with the things above, most of the pawns are held in a balance that is very detrimental to the pawnbroker and very 
beneficial to the moneylender. Thus, the pawn represents extortion practices, which contradicts the principles of Indonesian socialism. Therefore, in the Basic Agrarian Law, liens are included in the category of "temporary" rights, which must be cultivated.

The rest of the land is taken by the Government, that is, if the land belongs to the person concerned. If the remaining land is pawned land, it must be returned to the owner. In the return of the pawned lands, of course there will be problems regarding the repayment of the pawned money. This regulation solves this problem, based on the facts as described above. that is, that in practice the yield of land received by the pawnbroker is far more than the interest it deserves than the money lent. According to the calculation, the mortgage holders on average have received back from the proceeds of the land within 5 to 10 years, plus the appropriate interest (10\%). In this regard, it is determined that land that has been pawned for 7 years (the middle number between 5 and 10 years) or more must be returned to the owner, without the obligation to pay a ransom. Regarding pledges that have not lasted for 7 years, as well as new pledges, provisions are made in Article 7 paragraphs 2 and 3 , in accordance with the principles mentioned above.

Regarding the time limit for the lien, it is regulated in Article 7 of the Law. No. 56 Prp Th. 1960 which reads:

1. Whoever controls agricultural land with a lien right which at the time this Regulation comes into force 7 years or more has been in place is obligated to return the land to its owner within a month after the existing crops have been harvested, with no right to demand a ransom payment.

2. Regarding liens which have not been effective for 7 years, the landowner has the right to ask for it back at any time after the existing plants have been harvested, by paying a ransom, the amount of which is calculated according to the formula: 


\section{$\frac{(7+1 / 2)-\text { Time of Lien }}{7} X$ Pawn Money $=$}

provided that at any time the lien has lasted for 7 years, the holder of the lien is obliged to return the land without payment of a ransom, within a month after the existing crops have been harvested.

3. The provisions in paragraph 2 of this article shall also apply to liens made after the entry into force of this Regulation. Then so that the provisions of this regulation can run and be implemented properly, then in article 10 criminal sanctions are held as necessary.

4. Sentenced to a maximum imprisonment of 3 months and/or a maximum fine of IDR 10,000: (a) whoever violates the prohibition contained in article 4; (b) any person who does not fulfill the obligations referred to in articles 3, 6 and 7 .

\section{Profile and Practice of Pawning Paddy Fields in Jambesari Village, Poncokusumo District, Malang Regency}

Most of the population of Jambesari Village, Poncokusumo District, Malang Regency make a living as farmers because the land is fertile, be it yards, fields, or rice fields, which are managed by young, old, men and women. So that land is the main target to meet daily needs. One of them is used as collateral because of the debt contract in the pawn agreement.

Pawning in the view of the people of Jambesari Village, Poncokusumo District, Malang Regency is a debt agreement by pledging something (land) from the pawner to the recipient of the pawn then the land is controlled by the murtahin to be used with a certain time limit, some also pawn the land without a time limit. ${ }^{25}$

If the pawnbroker is unable to pay the debt, the land is still used by the murtahin until the murtahin can pay off the

${ }^{25}$ Anik Anggraini, Wawancara, Pabrikan, 24 juli 2019. 
debt. ${ }^{26}$ The Pawn Pawn Agreement often occurs between individuals, usually the pawnbroker is looking for someone who is deemed able to give him the amount of money he needs. For the implementation of the practice of pawning fields, there is no specific reference, it just refers to the habits of the people of Jambesari Village, Poncokusumo District, Malang Regency which have been going on for generations.

Another factor is for business capital, as did Mr. Yusuf who pawned his land to Mrs. Sulikah, he is a successful vegetable trader. He said that Mr. Yusuf pawned his land for 5 years with a credit given by busulikan as much as 100 million and Mr. Yusuf extended the mortgage period with an additional 3 years with a debt of 50 million, so the total was 150 million in a period of 8 years, but Some time ago there was no news of Mr. Yusuf's whereabouts, which should have been due in 2019. ${ }^{27}$

In the opinion of Mr. Eko Agus as the Head of the Manufacturing Hamlet, he said that the people of Jambesari Village recognize Pawning fields as a form of debt and receivables with collateral, namely rice fields. The first process is that the party who needs money comes to someone who is able to provide a loan of money. Then they made a verbal agreement regarding the amount of money needed and the time to pawn the fields, after they agreed then the land became collateral for the debt and was managed by the creditor for the duration of the agreement. ${ }^{28}$

The practice of pawning rice fields is usually carried out by farmers, namely individual by individual. The implementation of this rice field pawning contract or agreement has adhered to the prevailing customs or culture and has been passed down from generation to generation and does not refer to procedures according to Islamic law or based on the law. Regarding the collateral used is rice fields, and the

\footnotetext{
${ }^{26}$ Jumali, Wawancara, Sumberjambe, 24 Mei 2019.

27 Sulikah, Wawancara, Sumberjambe, 26 Mei 2019.

${ }^{28}$ Eko Agus, Wawancara, Pabrikan, 27 Mei 2019.
} 
use of the land will automatically be held and utilized by the recipient of the pawn. ${ }^{29}$

The pawnbroker comes to the residence of the pawnee and conveys his purpose before the pawn contract takes place. If it is confirmed that the pawnbroker already knows the condition of the paddy field to be pawned and has agreed to this contract, then an agreement occurs between the two. In general, this field pawn contract occurs when someone needs a large amount of money. And want to get it immediately with an easy and fast process. As did Mr. Sanan, a resident of RT 27 RW 06, who pawned his land to his brother for business purposes, namely, to build a laying hens coop. ${ }^{30}$

Furthermore, before the pawning of the fields occurs, the recipient of the pawn must first ensure the condition of the fields, the estimated price, then the murtahin will give the debt to Rahin an amount of money with a benchmark that it does not exceed the selling price of the pawned land. This aims to equalize the agreement between the pawn and the recipient of the mace.

Another pawning practice was carried out by the residents of Sumberjambe Hamlet, namely the family of the late Mbok Marsiem, the first child named Tasuwan pawned the land and received a debt of 1 cow to the late Pak Mail. This contract has been going on for \pm 40 years. Finally, his grandson tried to redeem the land to Mr. Mail's family about \pm 20 years ago, but Mr. Mail's family refused on the grounds that they were not satisfied with managing the land. After 20 years later, Mbok Marsiem's family returned by demanding that the land be returned to Mbok Marsiem's family and tried to redeem it with an amount of Rp. 60,000,000, - finally by the recipient of the land pawn it was returned to the family of Mbok Marsiem. ${ }^{31}$

${ }^{29}$ Sanun, Wawancara, Sumberjambe, 10 Juni 2019.

${ }^{30}$ Sanan, Wawancara, Jambesari, 27 Mei 2019.

${ }^{31}$ Ba'i, Wawancara, Sumberjambe, 13 Juni 2019. 
Briefly, the process of Pawning Rice Fields in Jambesari Village, Poncokusumo District, Malang Regency is as follows:

1. The pawnbroker comes to the murtahin to convey his meaning in terms of debts.

2. The recipient of the pawn considers the amount of debt that is adjusted to the condition of the land.

3. Make a field pawn agreement between the pawner and the pawnee.

4. Then after the receivables are given by the pawnee, the land is given to the pawnee to be used as collateral until the pawner can pay off the debt according to the stipulated time.

5. If within the stipulated period the pawner has not been able to pay the debt, the land remains in the possession of the pawnee for an indefinite period, so that the pawner is able to pay off the debt.

6. Utilization is in the hands of the pawnee.

The reasons for each pawnbroker are different, starting to be used for daily needs, business capital, celebration needs, for overseas expenses to childbirth costs. The amount of debt also varies from a small amount, namely Rp. 4,000,000 up to Rp. $100,000,000$. Regarding the debt benchmark, there is no limit. However, it still does not exceed the price range of the pawned rice fields. They borrow money according to their needs. The time that has been set can still be tolerated, because most of them pawn their fields to their own families and they are not worried that their debts will not be repaid. ${ }^{32}$

As mentioned above, the authors found several problems that occurred in the Pawn Paddy Practice in Jambesari Village, Poncokusumo District, Malang Regency as follows; (1) there is no profit sharing on the use of goods by the pawnee; (2) the protracted practice of pawning rice fields. This happens when the pawnbroker is unable to pay off his debt when it is due. The land will be managed by the pawnbroker

\footnotetext{
32 Anik Anggraini, Wawancara, Pabrikan, 24 Juli 2019.
} 
until the pawnbroker can pay off the debt, no matter how long and when the pawnee will pay off the debt. These problems occur because of the lack of knowledge about pawning, especially knowledge of pawning in accordance with Islamic law and positive law.

\section{Public Opinion on Pawn Paddy Practice}

This is related to the practice of pawning rice fields in Jambesari Village, Poncokusumo District, Malang Regency in terms of using the pledge of pawning rice fields by the recipient and there is no time limit. When the pawnbroker cannot pay off his debt, there are several opinions of leaders in Jambesari Village, Poncokusumo District, Malang Regency, including the following:

Jambesari Village officials, namely Mr. Eko Agus Siswanto As PLH Jambesari Village Head, according to him the pawning of rice fields that occurred was a debt agreement, related to the use of land by the recipient of the pawn he said the contract was allowed, but must be in accordance with the agreement made, but when it fell when the recipient of the mortgage is still unable to pay off the debt, then there is an extension. Extensions without such time limit are not permitted. ${ }^{33}$

Mr. Jumali he is a Mudin in Jambesari village, Poncokosumo District, Malang Regency. In his opinion about the use of the pledged land, he said that this is a common occurrence in Jambesari, Poncokosumo sub-district, Malang Regency. Because when the person pawns the land automatically the land will be fully managed by the pawnee. Regarding the unlimited time, he said that oneju did not agree, but what about it because this has become a habit of the people ${ }^{34}$

${ }^{33}$ Eko Agus Siswanto, Wawancara, Jambesari, 25 Mei 2019.

34 Jumali, Wawancara, Sumberjambe, 24 Mei 2019. 
Meanwhile, according to religious figures from Jambesari Village, such as Ustadz Muliadi, he is a takmir of the Al-Huda Mosque in Sumberjambe hamlet. He said that the pawn contract is a contract between a person and another person who requires a certain amount of money to meet his needs. Regarding the use of land, it depends on the agreement of the person with the contract. Meanwhile, regarding the extension of time that there is no limit, he does not agree. His reason is because the extension of time can harm the pawner. ${ }^{35}$

Community leaders such as Abah Sanun is a community leader, one of the elders in Jambesari Village. In his opinion on the use of the pawned land by the pawnee, there are priests who allow it, and some do not, but in this village the custom of the land when it is in the hands of the pawnee will automatically be managed by the pawnee, whether it has received permission from the pawnbroker or not, because this has become a habit for the people of Jambesari Village, Poncokosumo District, Malang Regency. Regarding the extension of time indefinitely, although this has become a habit, he does not agree. Because the unlimited time will be very profitable for the recipient of the pawn with agricultural products that he continues to manage and detrimental for the pawner who is increasingly difficult to pay off, arguing that the land is the medium from which he should earn income. ${ }^{36}$

\section{Analysis of Islamic Law and Law no. 56 Prp 1960 Against Paddy Paddy Practices in Jambesari Village, Poncokusumo District, Malang Regency}

In the previous chapter, the author has described the practice of pawning rice fields by the people of Jambesari Village, Poncokusumo District, Malang Regency. From the data obtained, the writers can analyze from various aspects including that the practice of pawning fields carried out by the

\footnotetext{
${ }^{35}$ Muliadi, Wawancara, Sumberjambe, 25 Mei 2019.

${ }^{36}$ Sanun, Wawancara, Sumberjambe, 10 Juni 2019.
} 
people of Jambesari Village, Poncokusumo District, Malang Regency is included in the Rahn contract. That is by making goods of value according to shara' as a guarantee of ability to pay off their debts to murtahin.

The rahn contract is considered valid when it meets the requirements and pillars. This is in accordance with the practice of pawning rice fields in Jambesari Village, Poncokusumo District, Malang Regency. The pillars of rahn include the following: ${ }^{37}$ (1) qidain, namely the person who performs the contract. Rāhin (person who pawned the land) and mutahin (person who received the pawn); (2) marhun, namely goods that are used as collateral; (3) marhun bih, namely debt; (4) contract shighat

The practice of pawning rice fields in Jambesari Village, Poncokusumo District, Malang Regency is legal and in accordance with Shari'at al-Islam because it has fulfilled the pillars. However, we need to see from the details of the analysis we can describe it as follows: (1) Aqidain, namely the person who performs the contract. Rahin as the pawnbroker has handed over the goods that are used as collateral to the murtahin and the mutahin as the person receiving the pawn has received the goods to be pawned rahin; (2) Marhun, namely goods that are used as collateral. In this case the land is used as collateral; (3) Marhun bih, namely debt in the form of money; (4) Shighat contract, which we can see from the verbal agreement between the two parties.

In terms of the pillars of rahn, the field pawning contract in Jambesari Village, Poncokusumo District, Malang Regency is in accordance with the provisions of shari'at al-Islam, as well as there are rahn conditions that must be met including the following: In the practice of pawning rice fields in Jambesari Village, it is declared valid, because both parties are someone

${ }^{37}$ Wahbah Az-zuhaili, Fiqih Islam Wa Adillatuhu (Jakarta: Gema Insani, 2007), 111. 
who is mature and has reason and is capable of taking legal action; (2) The requirements of the marhun are that the goods are valuable, can be traded, clear and certain, lawful and constitute the legal ownership of the rahin. From these requirements, the practice of pawning fields has met the criteria and the collateral is in the form of land that can be used and can also be traded.

(3) Marhun bih, namely receivables belonging to the murtahin to rahin which must be returned to the murtahin when the time is due. In this case, of course, the marhun bih in the hands of rahin will be returned to the murtahin according to the amount owed; and (4) Shighat or ijab qabul is the result of an agreement between rahin and murtahin. Hanafiyah scholars are of the opinion that a contract should not be associated with certain conditions, because basically this pledge contract is the same as a sale and purchase contract. In debt-receivable contracts that make benefits and the form of debt that flows benefits is usury. ${ }^{38}$ In a hadith the Prophet Muhammad explained: "Every debt that attracts benefits is usury" (HR. al-Baihaqi) ${ }^{39}$

It is forbidden to use pawned fields for murtahin, people who lend money should be solely for the sake of Allah, not for profit. In Islam, it is forbidden to take advantage of opportunities in adversity. People need to be desperate and usually the permission is because they have to because they have to pay debts. Even if the person is rich, it must be taken care of. The murtahin can work on the rice fields but there is a calculation, namely the rent and rent are deducted from the debt of the rahin, it is valid if the murtahin works on the land of the rahin automatically the debt of the rahin is reduced according to the agreement. If you just use it you can't because it's not a rental contract. It could be allowed for fear of not

38 Enang Hidayat, Transaksi Ekonomi Syariah (Bandung: PT Remaja Rosdakarya, 2018), 197.

39 Abdullah bin Abdurrahman, Taudih al-Ahkam Bulugh al-Maram, juz 4 (Makkatul Mukarromah: Maktabah Adh-Dhikri), 472. 
being given the debt. Where do you want to pay the debt when the land is managed by the murtahin?

Judging from the rahn requirements, the practice that occurs in Jambesari Village, Poncokusumo sub-district, Malang Regency, there are conditions that are not fulfilled, namely in shighat it must be associated with a requirement that is related to the full use of goods guaranteed by the murtahin without any profit sharing on the results of its management. With the conditions of management by the murtahin, there are positive and negative values. From a positive point of view, rahin can meet their needs with the proceeds of the mortgage, for murtahin to get a guarantee, so they don't worry that their debt will not be repaid and benefit from the results of land management as long as the money is borrowed by rahin. On the negative side, apart from having to pay debts, rahin cannot manage the land, which if managed, the results of the land management could be used to pay off her debts.

In addition to having to meet the pillars and conditions of the pledge, in Law no. 56 Prp Th. 1960 Article 7 Paragraph (1) "Whoever controls agricultural land with a lien right which at the time this Regulation comes into force 7 years or more is obligated to return the land to its owner within a month after the existing crops have been harvested, with no right to demand a ransom." In this case, the practice that occurs in Jambesari Village, Poncokusumo District, Malang Regency is contrary to these rules.

In the general provisions of Law no. 56 Prp Th. 1960 number (9) explains that according to calculations, the average mortgage has been received back by the pawnbroker from the land they manage within 5 to 10 years, plus a decent interest $(10 \%)$. In this regard, it is determined that land that has been pawned for 7 years (the middle number between 5 and 10 years) or more must be returned to the owner, without the obligation to pay a ransom.

Regarding pledges that have not lasted for 7 years, as well as new pledges, provisions are made in Article 7

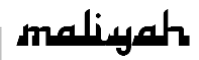


paragraphs 2 and 3 , in accordance with the principles mentioned above. That there are people who have excess land while most others do not have or not enough. This is clearly contrary to the principle of Indonesian socialism, which requires an equal distribution of the sources of livelihood for the peasants in the form of land, so that there is a fair and even distribution of the results of these lands. The possession of large tracts of land in the hands of a small number of farmers also opened up the possibility of extortion in all forms. this also contradicts the principles of Indonesian socialism.

From the description above, the writer can conclude that the practice of pawning rice fields that occurred in Jambesari Village, Poncokusumo District, Malang Regency is contrary to Article (7) Paragraph 1 of Law no. 56 Prp Th. 1960, the article explains that: Whoever controls agricultural land with a lien right which at the time this regulation comes into force 7 years or more is obligated to return the land to its owner within a month after the existing crops have been harvested, with no right to demanding a ransom payment, while at the same time there is no obligation for the pawner to redeem his land back.

Meanwhile, in the practice of pawning the fields in Jambesari Village, Poncokusumo District, Malang Regency, it has been going on for \pm 40 years and the land can be returned to the pawnbroker on condition that a ransom of $\mathrm{Rp}$. The \pm 40 years is enough for the pawnbroker to make a profit. In addition, regarding the use of land which is fully controlled by the pawnbroker, which opens up the possibility of extortion in all forms. this also contradicts the principles of Indonesian socialism.

The correct practice of pawning fields according to the Law. 56 Prp Th. 1960 concerning Determination of Agricultural Land Areas are as follows; If the land is fully managed by the creditor, after 7 years the land will be returned to the owner without any refund. thus is the interest on the debt. Redemption of the land depends on the will and ability of the 
mortgagee. in some areas also known as pawns where the yield of the land is not only interest, but also installments. Such a pawn is called a gangsur sale. However, it is also seen from the level of fertility of the land it manages, so that the calculation is sufficient according to the amount of debt.

The practice of pawning rice fields which is contrary to Article 7 Paragraph (1) of Law no. 56 Prp Th. 1960, sanctions will be given in accordance with Article 10 Paragraph (1) letter (b) which reads "Whoever does not carry out the obligations referred to in Articles 3, 6 and 7 (1) will be punished with imprisonment for a maximum of 3 months and/or a fine of as much as 3 months. -the amount is Rp. 10,000". This article applies to one of the pawnbrokers in Jambesari Village, Poncokusumo District, Malang Regency, namely Mr. Mail who has used Mbok Marsiem's pawned land for \pm 40 years and is still asking for a ransom from rahin, namely Mbok Marsiem in the amount of Rp. 60,000,000.

\section{Closing}

First, the practice of pawning rice fields by the people of Jambesari Village, Poncokusumo Subdistrict, Malang Regency is carried out by the pawnbroker and the pawn recipient make a verbal agreement to pawn the fields to the pawn recipient in \pm 1979 , then after the receivables are given by the pawn recipient to the pawner in the form of one piece. cattle, the land is given to the recipient of the pawn to be used as collateral until the pawnbroker can pay off the debt according to the time specified. If the pawner has not been able to pay the debt, then the land remains in the possession of the pawnee indefinitely and this practice has been going on for \pm 40 years.

Second, the practice of pawning rice fields in Jambesari Village, Poncokusumo District, Malang Regency is in accordance with the opinion of the Hanafi cleric because according to him, when permission from Rahin is obtained in terms of using pawned land, the land may be used by the recipient of the pawn and it is contrary to the majority of Maliki, Syafi'i and Islamic scholars. Hanbali because according 
to them they are happy and the permits given related to the use of the pawned land tend to be forced, namely there is a concern about not getting a debt loan. As for the absence of a time limit for paying off debt in a pawn, it is contrary to Article 7 paragraph (1) of Law no. 56 Prp Th. 1960.

\section{Bibliography}

Amanah, Nina. "Tinjauan Hukum Islam Terhadap Praktik Gadai

Sawah Di Desa Sindangjaya Kecamatan Ketanggungan Kabupaten Brebes". Skripsi--UIN Walisongo, Semarang, 2017.

Anshori, Abdul Ghofur. Hukum Perjanjian Islam Di Indonesia. Yogyakarta: Gadjah University Press, 2018.

Azhar. Ahmad Basyir. Asas-asas Hukum Mu'amalat: Hukum Perdata Islam. Yogyakarta: UII Press, t.t.

Abdullah bin Abdurrahman. Taud\{ih al-Ahkam Bulughul Maram juz 4. Makkatul Mukarromah: Maktabah Adh-Dhikri, t.t.

Darmono. "Tinjauan Hukum Islam terhadap Gadai Gantung

Sawah Di Desa Cilandak Lor Kecamatan Anjatan Kabupaten Indramayu". Skripsi--UIN Sunan Kalijaga, Yogyakarta, 2013.

Fatihudin, Didin. Metodologi Penelitiain. Sidoarjo: Zimatama, 2015.

Fauzan, Rizki. Fiqih Sunnah Imam Syafi'i, Depok: Fathan Media Prima, t.t.

Ghazaly, Abd. Rahman. Fiqh Muamalat. Surabaya: Prenada Media, 2018.

Harun, Nasroen. Fiqh Muamalah. Jakarta: Gaya Media Pratama, 2000.

Hidayat, Enang. Transaksi Ekonomi Syariah. Bandung: PT Remaja Rosdakarya, 2018.

Husain, Abdur Rahman Shobir. Al-Sabil Fi Ushul Al-Fiqh, juz 13. Libanon: Dki, 1971.

Kementrian Agama RI. Al-Qur'an dan Terjemahanya. Surabaya: UD Halim, 2013.

Manan, Abdul. Pembaruan Hukum Islam Di Indonesia. Jakarta: Kencana, 2017. 
Mardani. Fiqh Ekonomi Syariah. Jakarta: Kencana, 2018.

Musa, Muhammad Yusuf. Pengantar Studi Fikih Islam. Jakarta: Pustaka Al-Kautsar, 2014.

Muslich, Ahmad Wardi. Fiqh Muamalat. Jakarta: Amzah, 2010.

Raco. Metode Penelitian Kualitatif. Jakarta: Grasindo, 2010.

Rahman, Abdul. Fiqh Muamalat. Jakarta: Kencana, 2010.

Rizqiyah, Alfafa. "Tradisi Sende Desa Gedangan Kecamatan

Mojowarno Kabupaten Jombang Dalam Perspektif Hukum Islam". Skripsi--UIN Sunan Ampel, Surabaya, 2018.

Rohidin. Buku Ajar Pengantar Hukum Islam: Dari Semenanjung Arabia hingga Indonesia. Yogyakarta: Lintang Rasi Aksara Books, 2018.

Rukajat, Ajat. Pendekatan Penelitian Kualitatif Qualitative Research Approach. Yogyakarta: Depublish, 2018.

Sabiq, Sayyid. Fikih Sunnah: terj. Kamaluddin A. Marzuki, et al. Bandung al-Ma'arif, 1997.

Sabiq, Sayyid. Fiqih Sunnah 4. Jakarta: Pena Pundi Aksara, 2006.

Shomad, Abd. Hukum Islam Penormaan Prinsip Syari'ah dalam Hukum Indonesia. Jakarta: Kencana, 2017.

Warjiyati, Sri. Memahami Dasar Ilmu Hukum: Konsep Dasar Ilmu Hukum, Surabaya: Prenada Media, 2018.

Sudirman. Fiqh Kontemporer (Contemporary Studies of Fiqh). Yogyakarta: Deepublish, 2018.

Sugiarto, Eko. Menyusun Proposal Penelitian Kualitatif: Skripsi dan Thesis. Yogyakarta: Diandra Kreatif, 2017.

Suhendi, Hendi. Fiqh Muamalah. Jakarta: PT. Raja Grafindo Persada, 2011.

Syuja (abu), Al-Qadhi. Fiqih Sunnah Imam Syafi'i, terj. Rizki Fauzan. Depok: Fathan Media Prima, t.t.

Yusuf, A. Muri. Metode Penelitian Kuantitatif, Kualitatif \& Penelitian Gabungan. Surabaya: Prenada Media, 2018.

Zamzam, Firdaus Fakhry. Aplikasi Metodologi Penelitian. Yogyakarta: CV. Budi Utama, 2018.

Zuhaili (az), Wahbah. Fiqih Islam Wa Adillatuhu. Jakarta: Gema Insani, 2007.

Data Sejarah Pemerintahan Desa Jambesari Tahun 2019. 
Analysis Of Islamic Law And Law No. 56 PRP 1960 On The Practice ...

\section{Undang-Undang Nomor 59 Prp Tahun 1960 Tentang Penetapan Luas Tanah Pertanian}

